\section{CULTURE TESTS FOR THE PLAGUE BACILLUS.}

To the Editor of THE LANCET.

SIR,-In having to distinguish this month certain bacilli from the bacillus pestis I have put through the sugars a culture from a case of the recent Harbin epidemic of pnenmonic and septicæmic plague. Through the same sugars I have put, too, a culture of bacillus pestis I had some two years ago from Dr. A. Stanley of Shanghai that has been kept active by the passage through mice. The results agree with those given in the Indian Plague Commission reports. You may possibly consider this fact worth recording. Glucose, acid formation in less than 24 hours ; maltose, acid formation in less than 24 hours ; levulose, acid formation in less than 24 hours; dextrose, acid formation in 24 hours ; mannite, acid formation in 24 hours ; galactose, acid formation in less than 48 hours; dextrin and salicin, acid formation in less than 48 hours. With lactose, saccharose, and inulin there was no acid formation. In no case was there prodution of gas. There was no change of colour in neutral red broth. I am, Sir, yours faithfully,

Peking, March 31st, 1911.

$$
\text { J. G. GIBB, M.D. Durh., F.R.C.S. Eng. }
$$

\section{A CORRECTION.}

\section{To the Editor of THE LANCET.}

SIR, - In the report of the Leeds and West Riding MedicoOhirurgical Society published in THE LANCET on April 22nd, p. 1078, there is a slight mistake in the record of my case of cancer of the common bile-duct. The words "the lower end of the cystic duct was ligatured" should read "the lower end of the common bile-duct was ligatured."

I am, Sir, yours faithfully,

Leeds, April 22nd, 1911.

H. LitTLEWOOD.

\section{LIVERPOOL.}

(FROM OUR OWN CORRESPONDENT.)

Yellow Fever in West Africa: Sir Rubert Boyce's Mission.

Sir Rubert Boyce, the professor of pathology at the University of Liverpool, who recently went to West Africa on a mission to investigate yellow fever there, has issued a report to the Colonial Office giving comprehensive details of his investigations. A little consideration, he says, will show that with the progress of civilisation and luxury on the Coast the conditions of mosquito-breeding have very materially altered. He advocates more house-tohouse inspection on the part of all the local sanitary authorities, and urges the necessity for pipe-borne watersupplies and the enforcement of bush-clearing regulations. He considers that there is not sufficient practical training given in tropical schools, and says that far more attention should be paid to the scientific education of young medical officers than at present, while he suggests that the mining companies should be induced to select only medical officers holding diplomas of the tropical schools and a diploma in public health. The time has come, he says, to frame a suitable British intercolonial quarantine measure, to extend it or bring about an international quarantine measure on the lines of the pan-American one.

The Schoot of Bygiene of the University of Liverpool.

The Liverpool School of Hygiene has arranged for a course of six lectures on milk-supply. These will deal with the composition of milk; the sanitation of cowsheds; the diseases which may be conveyed by milk; and legislation affecting the production and sale of milk. The series of lectures commenced on Thursday, April 20th, at the Ashton Hall in the University, and will be continued each following Thursday. The addresses are calculated to be of exceptional interest and benefit to the community.

\section{Runcorn Cottage Tospitat.}

Mr. F. J. Norman of Runcorn has presented a new wing to the Runcorn Oottage Hospital, together with a block of six "citizens' homes" for aged poor cripples. Each house has been prettily furnished in oak. The gifts are unconditional, and the homes may be occupied at a rental of $6 d$. per week by poor people of any creed. The expenditure on the buildings amounts to £2000. The wing and "homes," which have been recently opened without formal ceremony, are dedicated to the memory of the late Mr. Thomas Norman, the father of the generous donor.

April 25th.

\section{SCOTLAND.}

(FrOM OUR OWN CORRESPONDENT.)

Scottish Vital Statistics.

THE annual report to the Registrar-General on Scottish vital statistics for 1910 has just been issued, along with the report on vaccination for 1909 . The reports, which are signed by Dr. J. Craufurd Dunlop, are, as usual, of considerable interest. Among the outstanding facts therein recorded are the lowness of the birth- and death-rates, the drop in the deaths from tuberculous disease, the number of deaths from malignant disease, and the very considerable increase in the proportion of unvaccinated children. The report points out that as it was nearly ten years since the last Census of Scotland was taken, errors in estimating population are likely to be considerable, and that therefore the estimates are given with reserve. The estimated population of Scotland in the middle of 1910 is $4,929,251$, and of these 46.5 per cent. live in the principal town registration districts. The birthrate for the year is 25.16 per 1000 , being the lowest Scottish annual birth-rate yet recorded. The rate is 1.20 less than in 1909 and $2 \cdot 16$ less than the average rate of the preceding five years. From 1855 to 1893 the national birth-rate varied between 30 and 35.6 per 1000 . Of the children born during the year 6.85 per cent. were illegitimate. The illegitimate rate was highest in the mainland rural districts. The deathrate was 14.66 per 1000 of the estimated population and the lowest Scottish death-rate yet recorded. The infantile mortality rate amounted to 122 per 1000 births. With regard to deaths from infectious diseases, it is shown that in the eight principal towns there was no serious epidemic, with the exception of an outbreak of measles. Cerebro-spinal mєningitis, which appeared in Scotland in epidemic form in 1906 and which caused 1018 deaths in the ejght principal towns in 1907, showed in 1910 only 39 deaths. Deaths from tuberculous disease numbered 3458, as against 3763 in 1909 and 3882 in 1908. On examining the death-rate from taberculosis in the eight principal towns, there is found to be, since 1901 , a decline of 30.3 per cent. in the death-rate from all tuberculous disease, while the decline in the phthisis rate is one of 35.2 per cent. The decline in the tuberculosis death-rate of the towns is most marked in Edinburgh. Deaths from malignant disease numbered 2017, as compared with 2031 in 1909 and 2151 in 1908. The weather conditions showed a normal mean temperature and a somewhat high average rainfall. Among the vaccination statistics, those are of most interest which deal with the evasion of vaccination. As was expected, there was again a large increase in the number of persons availing themselves of the opportunity for evasion provided by the 1906 Vaccination (Scotland) Act. The number of persons signing the conscientious objections clause in 1909 was 22.746 , as against 15,846 in 1908, 7258 in 1907, and '253 in 1906, the year of the passing of the Act. It is estimated that the Act must be held responsible for adding to the population 25,000 unvaccinated children in 1909 , or a total of 45,000 in the course of 1908 and 1909 . The figures for 1910 do not become available until 1912. As has been pointed out before, the Act above mentioned does not require of the parent any declaration of conscientious objections to vaccination in general, but merely a statement that in his opinion vaccination would be prejudicial to the health of the particular child named.

April 24th.

The Bostock Scholarship.-An examination for this scholarship, of the value of $£ 60$ a year, and tenable for two or four years at the London (Royal Free Hospital) School of Medicine for Women, will be held by the University of London on June 5th. Particulars may be obtained on application to the secretary of the school, 8, Hunter-street, W.O. 